\title{
TRANSFER PRICING FOR COOPERATION OF SUPPORTING CENTRES IN METALLURGICAL PRODUCTION
}

\author{
Josef KUTÁČ, Tomáš KUTÁČ, Kamila JANOVSKÁ, Eva ŠVECOVÁ \\ VSB - Technical University of Ostrava, Ostrava, Czech Republic, EU \\ josef.kutac@vsb.cz, tomas.kutac@vsb.cz,kamila.janovska@vsb.cz, eva.svecova@vsb.cz
}

https://doi.org/10.37904/metal.2019.980

\begin{abstract}
The article deals with the ways of the most accurate calculation in the intercompany prices of the cooperating centres activities, which transmit their activities in such a way that transfer cycles occur. Examples include mutual transfers of Maintenance and Energy centres, where activities is transferred from Maintenance to Energy and also from Energy to Maintenance centre [1]. In this article, the transfer prices are considered on the basis of their own costs.
\end{abstract}

Keywords: Transfer pricing, intercompany activities transfer, custom costs, supporting centres, final centres, primary costs, secondary costs

\section{INTRODUCTION}

At the very beginning of the process of calculating the transfer pricing of their activities (based on its own cost), the intercompany mutually cooperating centres have only primary costs, which they use to evaluate their transfer to consuming centres. Intermediate transfers between centres then generate secondary costs, by the amount of which should be increased the output prices. Mathematical and practical possibilities for addressing this issue are the aim of this article.

The cooperating centres in the metallurgical enterprises are both final (main) centres and supporting centres. Final centres are the production centres within those metallurgical stages of production that transfer their products to the finished goods warehouse, i.e. those stages of production which products are sold for sale to external customers. This is mainly rolling mills and finishing lanes (slitting, levelling, profiling, ...), but also coke plants, blast furnaces or steel continuous casting centres, which may also sell part of their products. The supporting centres are then understood as production centres with incomplete production process, which transmit their products to other production centres in the form of semi-finished products, and service centres, which include maintenance [2], transport and energy etc. The goal of the whole process of transfer pricing is aimed at transferring primary costs of supporting centres to final centres in the form of secondary costs. Subsequently, these total costs (primary and secondary) are allocated from the final centres for their individual activities (products) in the evaluation of their calculations.

The problem in calculating transfer prices of intercompany activities is primarily the existence of mutual transfer cycles, where the centres deliver their activities to the centres from which they also withdraw their activities, as shown in the Figure 1 in a simple example.

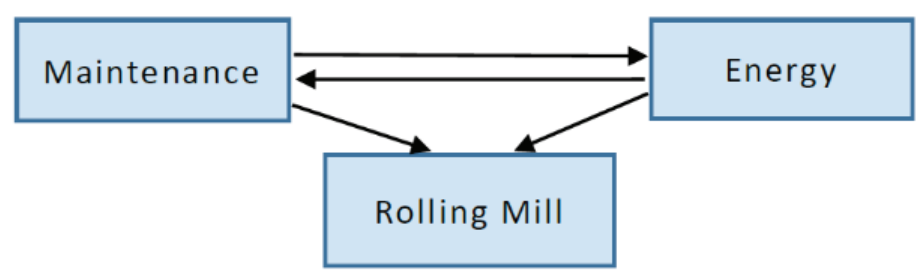

Figure 1 An example of a mutual transfer cycle between Maintenance and Energy centres 
There are basically three methods of calculating activities transfer prices of cooperating centres:

- $\quad$ direct method,

- $\quad$ step method,

- $\quad$ reciprocal method.

\section{DIRECT METHOD OF TRANSFER PRICES CALCULATION}

Direct method covers the evaluation of all internal activities transfer including reciprocal cycles of these transfers so that the transfer prices are calculated only for the final centres just from the primary cost of supporting centres and from the amount of activities transmitted to the final centres in kind. This simple calculation method, however, is very inaccurate because it does not take into account the transfer between supporting centres [3].

The more reciprocal transfers between the more supporting centres and the more final centres the activities is transferred to, the less accurate the calculation of the price of each transmitted intercompany activities using the direct method, and the less accurate the transferring primary costs from supporting centres to final centres.

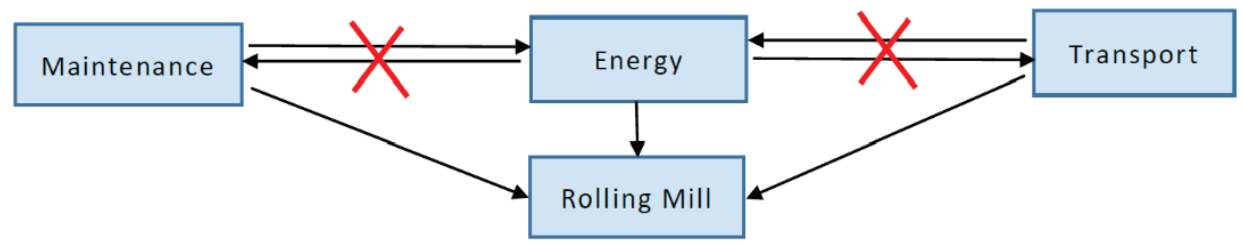

Figure 2 Example of a direct method transfer evaluation of Maintenance and Energy centres to the Rolling Mill centre

However, if there is only one final centre, as shown in the Figure 2 above, then at any number of support centres and any number of interchange cycles, it is unnecessary to use a method other than direct, as secondary costs will not be refined at the final Rolling Mill centre. This is due to the fact that the sum of the secondary costs of all final centres (one final centre) must always be equal to the sum of all primary costs of all supporting centres.

For a direct method of calculating the cost of intercompany transfers at the level of own costs, it is necessary to know not only the primary own costs of the individual supporting centres, but also the amount of activities transferred by these centres in kind.

The transfer price of supporting centres to the main centre within the direct method is calculated using the Equation 1.

$T P_{i}=\frac{Z_{i}}{X_{i}}$

where:

$\mathrm{TP}_{\mathrm{i}}$ - Transfer Price of Support Centre $\mathrm{i}(\mathrm{i}=1 \ldots \mathrm{n})$

$Z_{i}$ - Primary Cost ofSupport Centre $i(i=1 \ldots n)$

$X_{i}$ - Value Cost Driver output of Support Centre $i(i=1 \ldots n)$

\section{STEP METHOD OF TRANSFER PRICES CALCULATION}

Step method as shown in the Figure 3 deals with mutual transfer between supporting centres but ignores the possible reciprocal cycles of these transfers. This means that it only allows a one-way transfer between two 
supporting centres. In the event of double-sided transfer between two centres, it is advisable not to take into account the cheaper transfer.

It is also necessary to determine the steps for calculating the individual transfer prices of the supporting centres, with the last centre transferring its activities to the final centre in the calculation. In other words, in the phase method, the transfers of the supporting centres are only transferred to those supporting centres, for which no activities from other supporting centres have been yet transferred [4].

This method is more accurate than the direct method if there are mutual transfer cycles, but it is more demanding.

It holds that the more mutual cycles of transfers between the supporting centres and the greater the number of final centres the activities is transferred to, the less accurate the calculation of the price of each transmitted intercompany activities by the step method, and the less accurate transfer of the primary costs of supporting centres to final centres.

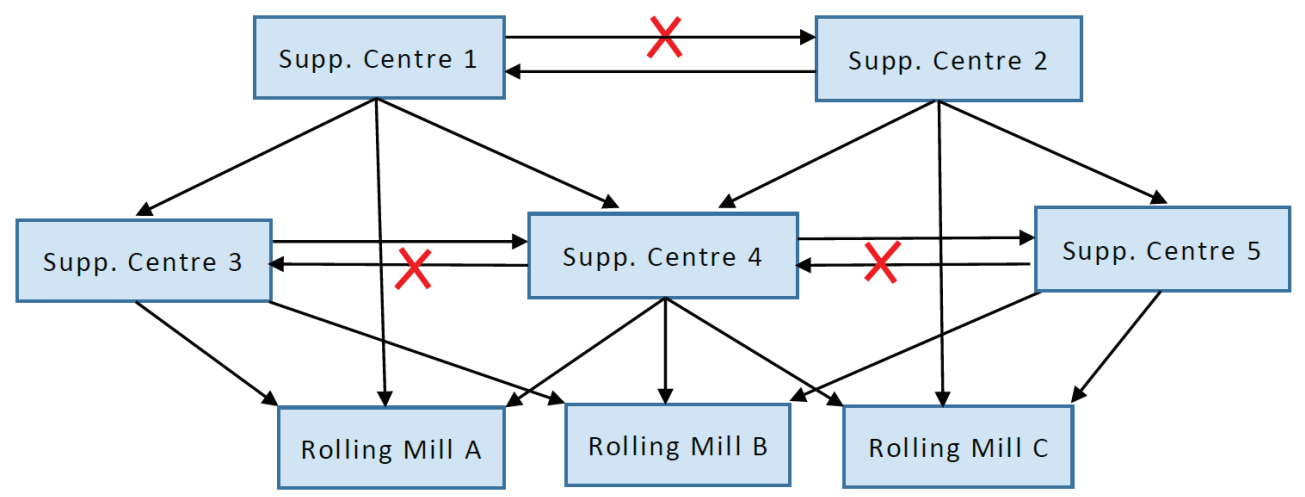

Figure 3 Example of a step method of evaluation of supporting centres transfer to final Rolling Mill centres

It holds that if there are any number of supporting centres with any number of mutual transfers, but only one final centre, it is sufficient to use the direct method of calculating the transfer pricing. Using the step method does not make this calculation more precise.

When using this method, it holds that the sum of the secondary costs of all final centres (one final centre) must always be equal to the sum of all primary costs of all supporting centres.

When using the step method to determine the cost of intracompany transfers at the level of own costs, it is necessary to know not only the primary own costs of individual supporting centres, but also the amount of transferred activities by these centres in kind.

The price of intercompany transfers from supporting centres to main centres is calculated according to the following Equations 2, 3, 4, 5:

$S C_{j}=\frac{T C_{i}}{X_{i}} \times x_{i j}$

where:

$\mathrm{SC}_{\mathrm{j}}$ - Secondary Cost of Support Centre $\mathrm{j}(\mathrm{j}=1 \ldots \mathrm{n})$

$\mathrm{TC}_{\mathrm{i}}$ - Total Cost of Support Centre $\mathrm{i}(\mathrm{i}=\mathrm{j}-1)$

$X_{i}$ - Value Cost Driver output of Support Centre $i(i=j-1)$

$x_{i j}$ - Value Cost Driver output of Support Centre i used inputs for Support Centre $j(j=1 \ldots n)$

$T C_{i}=Z_{i}+S C_{i}$ 
where:

$T C_{i}$ - Total Cost of Support Centre $i(i=j-1)$

$Z_{i}$ - Primary Cost of Support Centre $i(i=j-1)$

$\mathrm{SC}_{\mathrm{i}}$ - Secondary Cost of Support Centre $\mathrm{i}(\mathrm{i}=\mathrm{j}-1)$

$T P_{j}=\left(\frac{T C_{i}}{X_{i}} \times x_{i j}+Z_{j}\right) / X_{j}$

or

$T P_{j}=\left(S C_{j}+Z_{j}\right) / X_{j}$

where:

$\mathrm{TP}_{\mathrm{j}}$ - Transfer Price of Support Centre $\mathrm{j}(\mathrm{j}=1 \ldots \mathrm{n})$

$\mathrm{TC}_{\mathrm{i}}$ - Total Cost of Support Centre i $(\mathrm{i}=\mathrm{j}-1)$

$X_{i}-$ Value Cost Driver output of Support Centre $i(i=j-1)$

$X_{j}$ - Value Cost Driver output of Support Centre $j(j=j \ldots n)$

$x_{i j}-$ Value Cost Driver output of Support Centre i used inputs for Support Centre j

$\mathrm{SC}_{\mathrm{j}}$ - Secondary Cost of Support Centre $\mathrm{j}(\mathrm{j}=1 \ldots \mathrm{n})$

$Z_{j}$ - Primary Cost of Support Centre j ( $\mathrm{j}=\mathrm{i}-1$ )

Example for Transfer Price calculation using phase method in case of five phases activity handover for Support Centre is in Equation 6.

$\left.T P_{3}=\left(\left(\left(\left(\left(\left(\frac{T C_{1}}{X_{1}} \times x_{12}+Z_{2}\right) / X_{2}\right) \times x_{23}+Z_{3}\right) / X_{3}\right) \times x_{34}+Z_{4}\right) / X_{4}\right) \times x_{45}+Z_{5}\right) / X_{5}$

\section{RECIPROCAL METHOD OF TRANSFER PRICES CALCULATION}

Reciprocal method as shown in the Figure $\mathbf{4}$ fully solves all intercompany transfers between supporting centres, including mutual cycles of these transfers. Reciprocal calculation method is used when solving mutual system of equations, where defined matrices contain all ties and mutual cycle transfers between both the supporting centres and the supporting and final (main) centres. The condition for the reciprocal method is that there is no self-consumption of activities, that is, the supporting centres do not consume their own activities. If this self-consumption occurs in practice, then it is necessary to disregard it for this kind of calculation.

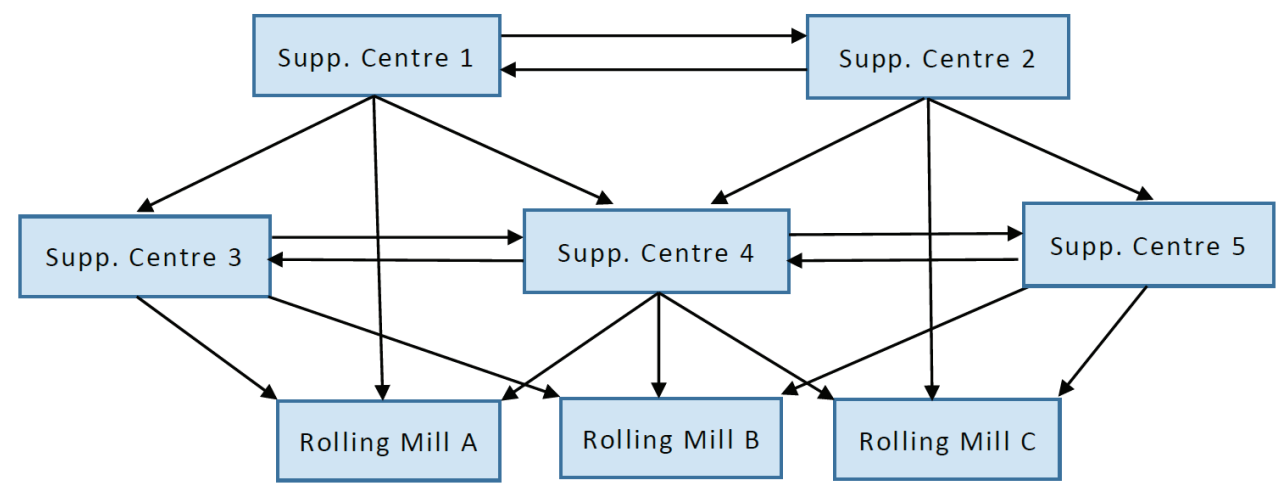

Figure 4 Example of the reciprocal method of evaluation of transfers from supporting centres to the final Rolling Mill centres 
For the reciprocal method holds that the sum of secondary costs of final centres must equal the sum of all primary costs of the supporting centres. When using the reciprocal method of calculating the prices of intercompany transfers at the level of own costs, it is necessary to know not only the primary own costs of the individual supporting centres, but also the amount of activities transferred by these centres in kind [5].

The intercompany transfer price from supporting centres to final centres is in the context of reciprocal method determined using a system of equations of mutual transfers as shown in the Table 1.

Table 1 General Input-Output Table - Absolute Value of Transfer

\begin{tabular}{|c|c|c|c|c|c|c|c|}
\hline \multicolumn{7}{|c|}{ General Input-Output Table - Absolute Value of Transfer } \\
\hline Support Centre & 1 & 2 & 3 & & $\mathrm{n}$ & Final Centre & Total Output \\
\hline 1 & $\mathrm{x}_{11}$ & $\mathrm{x}_{12}$ & $\mathrm{x}_{13}$ & $\ldots$ & $\mathrm{x}_{1 \mathrm{n}}$ & $\mathrm{y}_{1}$ & $\mathrm{X}_{1}$ \\
\hline 2 & $\mathrm{x}_{21}$ & $\mathrm{x}_{22}$ & $\mathrm{x}_{23}$ & $\ldots$ & $\mathrm{x}_{2 \mathrm{n}}$ & $\mathrm{y}_{2}$ & $\mathrm{X}_{2}$ \\
\hline 3 & $\mathrm{x}_{31}$ & $\mathrm{x}_{32}$ & $\mathrm{x}_{33}$ & $\ldots$ & $\mathrm{x}_{3 \mathrm{n}}$ & $\mathrm{y}_{3}$ & $\mathrm{X}_{3}$ \\
\hline $\mathrm{n}$ & $:$ & $:$ & $:$ & $:$ & $:$ & $:$ & $:$ \\
\hline Primary Cost & $\mathrm{x}_{\mathrm{n} 1}$ & $\mathrm{x}_{\mathrm{n} 2}$ & $\mathrm{x}_{\mathrm{n} 3}$ & $\ldots$ & $\mathrm{x}_{\mathrm{nn}}$ & $\mathrm{y}_{\mathrm{n}}$ & $\mathrm{X}_{\mathrm{n}}$ \\
\hline Total Output & $\mathrm{z}_{1}$ & $\mathrm{z}_{2}$ & $\mathrm{z}_{3}$ & $\ldots$ & $\mathrm{z}_{\mathrm{n}}$ & \\
\hline
\end{tabular}

For calculation using matrixes is necessary to transfer absolute values in I. quadrant to relative values, using Equation 7 and as shown in the Table 2.

$a_{i j}=\frac{x_{i j}}{X_{j}} \times x_{i j}$

Table 2 General Input-Output Table - Relative Value of Transfer

\begin{tabular}{|c|c|c|c|c|c|c|c|}
\hline \multicolumn{8}{|c|}{ General Input-Output Table - Relative Value of Transfer } \\
\hline Support Centre & 1 & 2 & 3 & & $\mathrm{n}$ & $\begin{array}{l}\text { Final } \\
\text { Centre }\end{array}$ & $\begin{array}{l}\text { Total } \\
\text { Output }\end{array}$ \\
\hline 1 & $a_{11}$ & $a_{12}$ & $a_{13}$ & $\ldots$ & $a_{1 n}$ & $\mathrm{y}_{1}$ & $\mathrm{X}_{1}$ \\
\hline 2 & $a_{21}$ & $a_{22}$ & $a_{23}$ & $\ldots$ & $a_{2 n}$ & $\mathrm{y}_{2}$ & $\mathrm{X}_{2}$ \\
\hline 3 & $a_{31}$ & $a_{32}$ & $a_{33}$ & $\ldots$ & $a_{3 n}$ & $\mathrm{y}_{3}$ & $\mathrm{X}_{3}$ \\
\hline : & : & . & : & : & : & : & : \\
\hline $\mathrm{n}$ & $a_{n 1}$ & $a_{n 2}$ & $a_{n 3}$ & $\ldots$ & $a_{n n}$ & $y_{n}$ & $X_{n}$ \\
\hline Primary Cost & $Z_{1}$ & $Z_{2}$ & $Z_{3}$ & $\ldots$ & $Z_{n}$ & & \\
\hline Total Output & $\mathrm{X}_{1}$ & $X_{2}$ & $X_{3}$ & $\ldots$ & $X_{5}$ & & \\
\hline
\end{tabular}

Particular quadrants in this table are source for creating of matrixes that are needed for calculation of transfer prices of supporting centres using structural model as per Leontief types [6]. 


\section{DISCUSSION}

The most accurate calculation of intercompany transfer prices is not so important for the responsibility management of supporting centres or for the evaluation of the production (semi-finished products), but is especially important for calculating price for price negotiations. Here, it is necessary to know the most accurate value of the costs consumed for the production of the final metallurgical product, not only the total cost of each production phase, but also the costs of activities consumed by supporting centres.

It is also very important, in view of the needs of evaluation for price negotiations, that all the above-mentioned calculations of intercompany transfer prices are made separately for variable and fixed part of own costs. This means that there should be two prices for each of intercompany activities transfer, in particular the transfer of supporting production centres, both in terms of variable costs, and fixed costs of supporting centres. Variability in this context means the relationship to the production volume of the final centre for which the activities is intended. This also applies to the evaluation of semi-finished products.

The breakdown of intercompany transfer prices to variable and fixed price components is important for the calculation of the interim contribution to cover fixed costs and profit for products of final centres. In the case of the evaluation of own-produced semi-finished products only at the level of total own costs, the calculated cover contribution for the products of the final centre concerns only the fixed costs of this final centre. Consumption of semi-finished products is then considered as a variable cost for this final centre, which can lead to incorrect decisions in the area of price negotiations.

\section{CONCLUSION}

The most accurate calculation of intercompany transfer prices is achieved by using Reciprocal method. In case of high number of supporting centers, especially supporting production centers, which transfer their activities to each other, this method is the most accurate, but very demanding for planning and tracking of primary costs and for amount of mutually transferred activities. Less accurate method is Step method and the least accurate method, but the easiest, is Direct method.

There is the rule that the more supporting centers exist the more accurate calculation of intercompany transfer prices should be. This is valid if we used Activity based costing method for example. This method is used for precise calculation of cost caused by specific activities. This is important for calculations used for selling price negotiation.

The best method for metallurgical industries as tube production, thin-walled welded products, railway wheelset production or iron foundry is Reciprocal method. Step method is appropriate for intercompany transfer price calculation in primary metallurgical production, as coke production, blast furnaces, steelworks or continuous steel casting. Direct method is not suitable for intercompany transfer price calculation in case of cross cooperation between supporting centers, especially when we want to use these calculations for selling price negotiation.

\section{ACKNOWLEDGEMENTS}

The work was supported by the specific university research of the Ministry of Education, Youth and Sports of the Czech Republic in VSB - Technical University of Ostrava No. SP2019/42.

\section{REFERENCES}

[1] TREBUNA, P., STRAKA, M., ROSOVA, A., MALINDZAKOVA, M. Petri nets as a tool for production streamliniing in plastics processing. Przemysl Chemiczny: Warszawa, 2015. vol. 94, no. 9, pp. 1605-1608. 
[2] SIKOROVÁ, A., LAMPA, M., SAMOLEJOVÁ, A. Analysis of maintenance costs in metallurgical enterprise. In METAL 2016: $25^{\text {th }}$ International Conference on Metallurgy and Materials. 25. 5.- 27. 5. 2016, Voroněž, Brno, Czech Republic. Ostrava: TANGER, 2016, pp. 2019-2025.

[3] POPESKO, Boris. Moderní řizení nákladů. Praha: Grada Publishing, 2009. p. 240.

[4] FIBÍROVÁ, Jana, ŠOLJAKOVÁ, Libuše, WAGNER, Jaroslav, PETERA, Petr. Manažerské účetnictví. Praha: Wolters Kluwer, 2015. p. 404.

[5] MACÍK, Karel. Kalkulace nákladů - Základ podnikového controllingu. Praha: Montanex, 1999. p. 241.

[6] KOPPANY, Krisztian. Estimating Growth Contributions by Structural Decomposition of Input-Output Tables. Acta Oeconomica [online]. 2017, vol. 67(4), pp. 605-642 [cit. 2019-01-27]. ISSN 00016373. Available from: https://akademiai.com/doi/pdf/10.1556/032.2017.67.4.6 